\title{
Electrochemical Detection of Linagliptin and its Interaction with DNA
}

\author{
Linagliptinin Elektrokimyasal Tespiti ve DNA ile Etkileşimi
}

\author{
(D) Seda Nur TOPKAYA ${ }^{1 *}$, (D) Hüseyin Oğuzhan KAYA1, (D) Arif E. CETIN2 \\ 1'zmir Katip Çelebi University Faculty of Pharmacy, Department of Analytical Chemistry, İzmir, Turkey \\ 2Izmir Biomedicine and Genome Center, İzmir, Turkey
}

\begin{abstract}
Objectives: Linagliptin (Lin) is a drug used in treatment of type 2 diabetes mellitus. In this study, the electrochemical detection of Lin and its interaction with DNA was analyzed for the first time using voltammetric methods by measuring the oxidation currents of the adenine bases of DNA before and after the interaction. In addition, the electrochemical properties of the Lin were studied.

Materials and Methods: The interaction between Lin and DNA was evaluated using differential pulse voltammetry. A three-electrode system comprising of a pencil graphite electrode as the working electrode, reference electrode $(\mathrm{Ag} / \mathrm{AgCl})$, and platinum wire as the auxiliary electrode was used in the electrochemical studies. Experimental conditions, such as the concentration, $\mathrm{pH}$ of the supporting electrolyte, and immobilization time were optimized to obtain maximum analytical signals.

Results: The adenine bases of DNA were evaluated as an analytical signal obtained at approximately $+1.2 \mathrm{~V} v \mathrm{vs}$. Ag/AgCl. After the Lin-DNA interaction, the oxidation currents of adenine decreased as proof of interaction. No reports have been published on Lin interacting with DNA. Based on our results, a diffusion-controlled irreversible redox process involving independent oxidation was revealed for Lin. Under optimum conditions, the detection limit was $6.7 \mu \mathrm{g} / \mathrm{mL}$ for DNA and $21.5 \mu \mathrm{g} / \mathrm{mL}$ for Lin. Based on the observations, Lin has a toxic effect on DNA.

Conclusion: We successfully demonstrated that Lin interacts with DNA, and its influence on DNA could play a vital role in the medical effect of the drug.
\end{abstract}

Key words: DNA, linagliptin, DNA-drug interaction, electrochemistry, voltammetry

öz

Amaç: Linagliptin (Lin), tip 2 diabetes mellitusun tedavisi için kullanılan bir ilaçtır. İlaçlar, ligandlar ve kimyasallar gibi küçük moleküller, kovalent ve kovalent olmayan etkileșimler yoluyla DNA ile etkileșime girebilmektedir. İlaçlar farmakolojik aktivitelerini farklı mekanizmalarla gösterdiklerinden, DNA ile etkileşimlerinin altında yatan mekanizmasını anlamak son derece önemlidir. Bu çalışmada Lin'in elektrokimyasal tespiti ve ilk defa DNA ile etkileşimi çalışması yapılmıştır. Bu etkileşim süreci birbirleriyle etkileşim öncesi ve sonrasında DNA adenin bazlarının yükseltgenme akımları ölçülerek voltametrik yöntemlerle analiz edilmiştir. Ayrıca çalışmamızda Lin'in elektrokimyasal özellikleri incelenmiştir.

Gereç ve Yöntemler: Lin ve DNA arasındaki etkileşim, diferansiyel puls voltametrisi kullanılarak değerlendirilmiştir. Bu elektrokimyasal temelli çalışmada; çalışma elektrodu olarak grafit uçlu kurşun kalem, bir referans elektrot $(\mathrm{Ag} / \mathrm{AgCl}$ ) ve yardımcı elektrot olarak bir platin telden oluşan üçlü elektrot sistemi kullanılmıștır. Maksimum analitik sinyalleri elde etmek için konsantrasyon, destekleyici elektrolitin pH'si ve immobilizasyon süresi gibi deneysel koșullar araştırılmıştır.

Bulgular: Çalışmamızda DNA-Lin etkileşimi; DNA ve Lin'in birbirleriyle etkileşimi öncesi ve sonrası adenine bazlarının Ag/AgCl referans elektroda karşı + 1.2 V'de verdiği yükseltgenme akımları karşılaștırılarak değerlendirilmiștir. DNA etkileșiminden sonra, adenin yükseltgenme akımları azalmıştır. Lin'in elektrokimyasal özelliklerinin araştırılması sonucu, bu molekül için difüzyon kontrollü, yükseltgenmeye bağlı ve geri dönüșümsüz bir redoks sürecinin meydana geldiği açığa çıkarılmıştır. Optimum koşullar altında, tespit sınırı DNA için sırasıyla 6,7 $\mu \mathrm{g} / \mathrm{mL}$ ve Lin için 21,5 $\mu \mathrm{g} / \mathrm{mL}$ olarak bulunmuștur. Elde edilen sonuçlar değerlendirildiğinde, Lin'in DNA üzerinde toksik bir etkiye sahip olduğu sonucuna varılmıştır.

Sonuç: Bu çalışmada elde edilen sonuçlar değerlendirildiğinde; elektrokimyasal metotlar kullanarak Lin'in DNA ile etkileşime girdiği hızlı ve başarılı bir şekilde gösterilmiştir.

Anahtar kelimeler: DNA, linagliptin, DNA-ilaç etkileșimi, elektrokimya, voltametri

*Correspondence: sedanur6@gmail.com, Phone: +90 507444 16 07, ORCID-ID: orcid.org/0000-0002-7816-3155

Received: 07.01.2021, Accepted: 28.02.2021

๑Turk J Pharm Sci, Published by Galenos Publishing House. 


\section{INTRODUCTION}

The interaction of small molecules, such as drugs, with DNA is important in pharmaceutical sciences. ${ }^{1,2}$ Such interactions can occur in a covalent or non-covalent manner. In covalent interactions, the bonding of a drug to DNA is irreversible, causing cell death. ${ }^{3}$ In non-covalent interactions, the bonding is reversible. A non-covalent interaction occurs mainly in three ways: Intercalation, groove binding, and electrostatic interaction. ${ }^{4}$ Among them, intercalation is the most powerful interaction mechanism. In minor groove binding, a close interplay with the groove wall occurs, and hydrogen bonds form between drugs and DNA. In a major groove, hydrogen binds to DNA, forming a DNA triplex. In electrostatic interactions, the interaction occurs between the molecule and negatively charged phosphates (PBS) yerine negatively charged phosphates..$^{5}$ The interaction between drugs and DNA can be monitored using voltammetry, ${ }^{6}$ electrochemical impedance spectroscopy, ${ }^{7}$ ultraviolet-visible spectroscopy, ${ }^{8}$ fluorescence spectroscopy, ${ }^{9}$ high-performance liquid chromatography (HPLC), ${ }^{10}$ fourier transform infrared and Raman spectroscopy," surface plasmon resonance, ${ }^{12}$ and molecular modeling methods. ${ }^{13}$ Among them, electrochemical methods, such as voltammetry and impedimetry, are generally preferred owing to their low cost, rapidness, and high sensitivity. In addition, compared with optical, chromatographic, or other transducers, electrochemical transduction is more dynamic and tunable.

Linagliptin (Lin) is a drug used for curing type 2 diabetes mellitus. ${ }^{14}$ Lin can be electrochemically detected through cyclic voltammetry $(\mathrm{CV})$ and square wave voltammetry using $\mathrm{Fe}_{2} \mathrm{O}_{3}$ modified carbon paste electrodes, ${ }^{15}$ and $\mathrm{Co}_{3} \mathrm{O}_{4}$ nanoparticles, and multiwalled carbon nanotubes-modified carbon paste electrodes. ${ }^{16}$ Spectrofluorometric ${ }^{17}$ and HPLC methods ${ }^{18}$ have also been reported for Lin quantification in human plasma and rat plasma, respectively. In addition, the HPLC-DAD method for Lin quantification in the presence of its degradation products in tablets has been studied. ${ }^{19}$

Herein, for the first time, we detected the interaction of Lin with DNA electrochemically using differential pulse voltammetry (DPV). In our study, the electrochemical properties of Lin were analyzed in the first step. Subsequently, we examined the oxidation signals of the adenine bases of DNA before and after the interaction with Lin. As DNA can acts as a molecular wire or a conductive bridge, the intrinsic electro-activity of DNA bases, such as adenine and guanine, could be used as an indicator for drug-DNA interaction in a label-free assay. In our study, we explored how the presence of Lin influenced the oxidation of adenine. Upon interaction with Lin, adenine oxidation currents decreased dramatically. In addition, experimental parameters, such as the concentration, $\mathrm{pH}$ of the supporting electrolyte, and immobilization time, were optimized to obtain the maximum current signals.

\section{MATERIALS AND METHODS}

\section{Equipment}

AUTOLAB apparatus connected to NOVA software (Metrohm, The Netherlands) was used for performing the voltammetric measurements. In all the experiments, pencil graphite electrodes (PGEs), $\mathrm{Ag} / \mathrm{AgCl}$, and platinum wire were used as the working, reference, and auxiliary electrodes, respectively.

\section{DNA and Lin}

Fish sperm double-stranded DNA (dsDNA) was purchased from Sigma-Aldrich (Germany). Stock solutions of DNA were prepared with tris-EDTA buffer (TE, $\mathrm{pH}$ : 8.0) and stored at $-20{ }^{\circ} \mathrm{C}$. Lin was purchased from Sigma-Aldrich, and $1 \mathrm{mg} / \mathrm{mL}$ of Lin stock solution was prepared with ultrapure water. During the experiments, 0.5-M acetate [(ACB), $\mathrm{pH}: 4.8$ ], 0.05-M (PBS, $\mathrm{pH}: 7.4)$, and 0.1-M sodium borate $(\mathrm{pH}$ : 8.1) buffers containing $0.02-\mathrm{M} \mathrm{NaCl}$ were used.

\section{Method}

Figure 1 shows the scheme for the experimental steps.

\section{Activation}

+1.4 V was applied to PGEs for $30 \mathrm{~s}$ in ACB for activation.

DNA and its immobilization (when only DNA is immobilized)

The stock solutions of DNA were diluted with ACB. The activated electrodes were immersed in $200 \mu \mathrm{g} / \mathrm{mL}$ of DNA solution for 1 $h$, and the electrodes were rinsed with ACB.

Lin and its immobilization (when only Lin is immobilized)

The stock solutions of Lin were diluted with ACB. The activated electrodes were immersed in $600 \mu \mathrm{g} / \mathrm{mL}$ of the drug solution
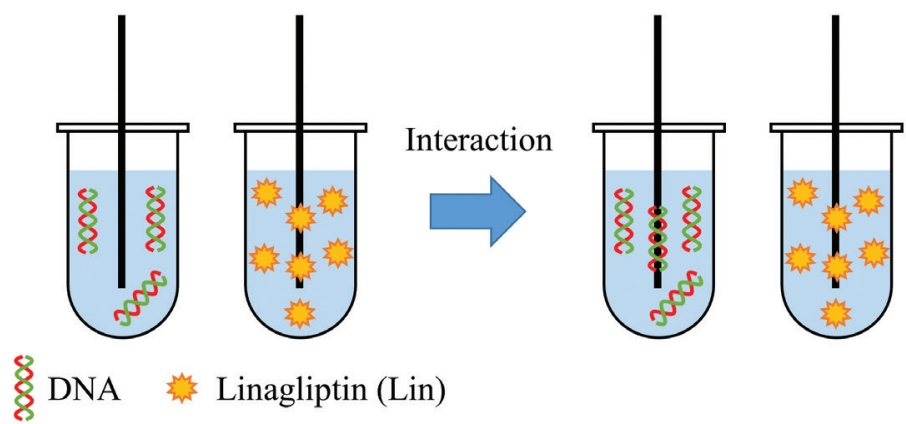

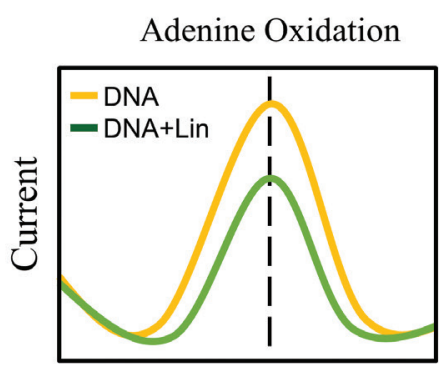

Potential

Figure 1. Experimental steps for the electrochemical detection of the interaction between DNA and Lin DPV: Differential pulse voltammetry 
for $1 \mathrm{~h}$ in the dark. Subsequently, the Lin-immobilized electrodes were rinsed with ACB.

\section{Interaction}

$400 \mu \mathrm{g} / \mathrm{mL}$ of DNA and $1200 \mu \mathrm{g} / \mathrm{mL}$ of Lin were mixed in the ratio of $1: 1$ in ACB. Thus, $200 \mu \mathrm{g} / \mathrm{mL}$ of DNA and $600 \mu \mathrm{g} / \mathrm{mL}$ of Lin solutions were obtained. Subsequently, $100 \mu \mathrm{L}$ of the solution was transferred into the vials. The electrodes were immersed in these vials for $1 \mathrm{~h}$ in the dark. Finally, the modified electrodes were rinsed with ACB.

\section{Measurement}

DPV measurements were carried out from +0.4 to $+1.4 \mathrm{~V}$ at a scan rate of $50 \mathrm{mV} / \mathrm{s}$ in ACB.

\section{Statistical analysis}

No standard statistical procedure was performed in the current study.

\section{RESULTS and DISCUSSION}

The electrochemical oxidation of DNA has been performed using carbon electrodes, among which PGEs have been applied to the largest extent. ${ }^{20}$ DNA bases are oxidized electrochemically at graphite electrodes, resulting in well-separated oxidation peaks on differential pulse voltammograms. The purine bases, such as guanine and adenine are negatively charged; on the other hand, the pyrimidine bases, such as cytosine and thymine, are positively charged. ${ }^{21}$ Consequently, the oxidation potential of guanine and adenine that is much lower when compared to the oxidation potential of cytosine and thymine. ${ }^{22}$ In general, the more negative peak $(+1.0 \mathrm{~V}$ vs. $\mathrm{Ag} / \mathrm{AgCl})$ corresponds to the electro-oxidation of guanine, whereas the more positive peak $(+1.2 \mathrm{~V}$ vs. $\mathrm{Ag} / \mathrm{AgCl})$ belongs to electro-oxidation of adenine. A dramatic decrease/increase at the oxidation/reduction peak currents of the drug (if the drug can be oxidized or reduced) or DNA, or potential shifts to the more positive or negative values can be used for the proof of interaction. Optimization studies for DNA, such as the concentration, immobilization time, and buffer prepared, were performed, and the corresponding results are shown in Figure 2.

To obtain maximum surface coverage, $25-200 \mu \mathrm{g} / \mathrm{mL}$ of DNA were adsorbed on the PGEs. As shown in Figure 2A, the peak currents of adenine increased with DNA concentrations (only linear values are shown in Figure 2A). A gradual increase was obtained until $200 \mu \mathrm{g} / \mathrm{mL}$ of DNA at PGE, and after this concentration, there was almost no change in the response. Thus, a DNA concentration of $200 \mu \mathrm{g} / \mathrm{mL}$ was selected as the optimum DNA concentration.

The limit of detection (LOD) and the limit of quantification (LOQ) were calculated in the concentration range between 25 and 200 $\mu \mathrm{g} / \mathrm{mL}$ of DNA. According to the calibration plot (Figure 2A), LOD and LOQ for DNA were calculated to be 6.7 and $22.3 \mu \mathrm{g} /$ $\mathrm{mL}$, respectively, using the equation LOD: $3 \mathrm{~s} / \mathrm{m}$, and LOQ: 10 $\mathrm{s} / \mathrm{m}$ ( $\mathrm{s}$ is the standard deviation for the blank solution, and $\mathrm{m}$ is the slope of the related calibration curve). ${ }^{23}$
Figure 2B shows the histograms of adenine oxidation currents as a function of immobilization time of DNA on the electrodes from 40 to $120 \mathrm{~min}$. Adenine oxidation currents slightly increased with time and remained nearly unchanged after 60 $\min$. As shown, long immobilization duration had no remarkable effect on the response. Thus, 60 min was selected.

The effect of the buffer solution where DNA prepared was investigated. Figure $2 \mathrm{C}$ shows the results. Clearly, the highest guanine $(+1.0 \mathrm{~V})$ and adenine $(+1.2 \mathrm{~V})$ oxidation currents were obtained with $A C B$ and further experiments were performed in ACB for the preparation of DNA solution.
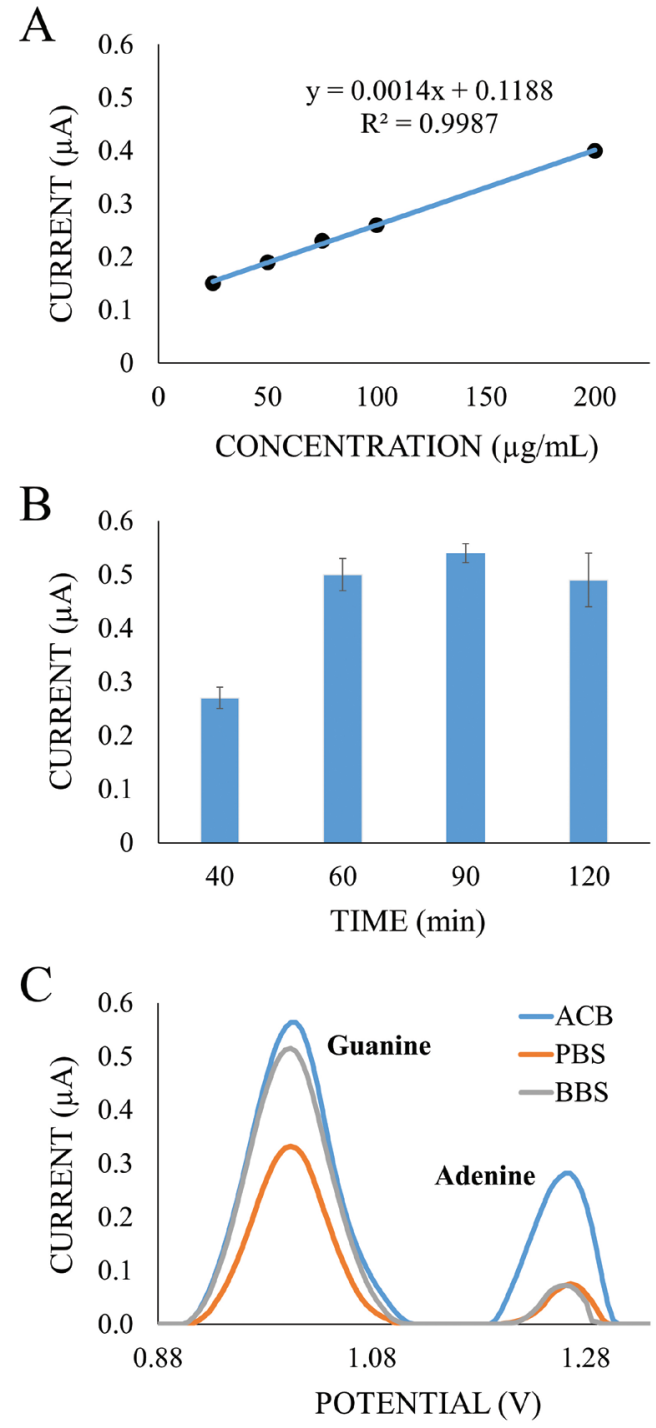

Figure 2. DNA optimization studies: (A) Calibration plot presenting adenine oxidation currents for DNA concentrations ranging from 25 to 200 $\mu \mathrm{g} / \mathrm{mL}$. (B) Histograms for average adenine oxidation currents for different immobilization times of DNA on the activated PGEs surface, e.g., 40 to $120 \mathrm{~min}$. (C) Differential pulse voltammograms of guanine and adenine oxidation currents obtained from different buffers where DNA prepared PGEs: Pencil graphite electrodes 
In Figure 3A, a differential pulse voltammogram is shown for the oxidation of Lin by scanning from +0.7 to $+1.1 \mathrm{~V}$ vs. $\mathrm{Ag} / \mathrm{AgCl}$ in ACB. As shown in Figure 3A, Lin has an irreversible anodic peak at nearly $+0.9 \mathrm{~V}$. Lin's chemical structure is also shown in Figure 3B. As shown previously, one proton could involve to the oxidation process resulting from the oxidation of amine group of piperidine ring. ${ }^{16}$

To optimize oxidation signals of Lin, various concentrations from 100 to $600 \mu \mathrm{g} / \mathrm{mL}$ of Lin were prepared, and their oxidation currents were measured with DPV (only calibration plot-linear values were showed in Figure 4A). As shown in Figure 4A, Lin oxidation currents obtained from nearly $+0.9 \mathrm{~V}$ signals were increased with the increased Lin concentration. The highest and reproducible Lin oxidation currents were measured in the presence of $600 \mu \mathrm{g} / \mathrm{mL}$ of Lin, and thus, this concentration was selected as the optimum concentration.

$L O D$ and $L O Q$ were calculated in the concentration range between 100 and $600 \mu \mathrm{g} / \mathrm{mL}$ of Lin. According to the calibration plot (Figure 4A), LOD and LOQ for Lin were calculated to be 21.5 and $71.67 \mu \mathrm{g} / \mathrm{mL}$, respectively.

The immobilization time, another parameter affecting the oxidation currents of Lin, was examined in the range of 5-120 min (Figure 4B). Lin oxidation current increased with time and remained nearly unchanged after $60 \mathrm{~min}$. Therefore, Lin immobilization time was chosen as $60 \mathrm{~min}$.

The effect of $\mathrm{pH}$ of the supporting electrolytes on the oxidation peak currents was investigated in the $\mathrm{pH}$ range from 3.7 to 9.8 (Figure $4 \mathrm{C}$ ). The Lin oxidation currents disappeared at $\mathrm{pH}$ 9.8. Therefore, we used three $\mathrm{pH}$ values $(3.7,4.8$, and 7.4) to analyze the effect of $\mathrm{pH}$. As shown in Figure 4C, the peak potential shifted toward more negative values as $\mathrm{pH}$ increased, demonstrating the involvement of protons during the oxidation process. $^{24}$ The highest peak current was observed in $\mathrm{pH}: 4.8$, and thus, this supporting electrolyte was chosen.

Over the $\mathrm{pH}$ range $3.7-7.4$, the anodic peak potential $\left(E p_{a}\right)$ of Lin varied linearly as a function of $\mathrm{pH}$ (Figure 4D). According to $E p_{a}-\mathrm{pH}$ behavior results, the equation is as follows:

$E p_{a}=-0.0189 p H+1.02 R^{2}=0.9997 \quad$ (equation 1)
The slope of equation $1(19 \mathrm{mV} / \mathrm{pH})$ is far from the ideal slope value of $59 \mathrm{mV} / \mathrm{pH}$, which suggests that the number of transferred protons and electrons are not equal. According to the literature, this result can be explained due to deprotonation or adsorption oxidation products that block electrode surface. ${ }^{25}$ The effect of scan rate $(v)$ on Lin oxidation currents was also analyzed with $\mathrm{CV}$. The peak currents (Ip) of Lin increased with increasing scan rate $(10$ to $100 \mathrm{mV} / \mathrm{s})$. According to the results, the equation is as follows:

$\log \mid p_{a}=0.6098 \log (v)+0.746\left(R^{2}=0.9756\right) \quad$ (equation 2)

According to equation 2, the slope of the above equation (0.6) is close to the theoretical value of 0.5 , which showed the occurrence of a diffusion-controlled electrode process. ${ }^{26}$

The relationship of $\mathrm{Ep}_{\mathrm{a}}$ between scan rates was analyzed with CV. According to the results, the equation is as follows:

$E p_{a}=0.0478 \log (v)+1.0426\left(R^{2}=0.9618\right)$

(equation 3)

The peak potential shifted slightly positively with increasing scan rate (10 to $100 \mathrm{mV} / \mathrm{s}$ ). This indicates that an irreversible electrochemical process has occurred. ${ }^{27}$

The relationship of the peak currents of $\operatorname{Lin}\left(I p_{a}\right)$ between roots of scan rate $\left(v^{1 / 2}\right)$ was also analyzed. According to the results, the equation is as follows:

$\operatorname{lp}_{a}(\mu A)=3.5219(v)^{1 / 2}+0.0598\left(R^{2}=0.9808\right) \quad$ (equation 4)

The linear increase in $\mathrm{Ip}_{\mathrm{a}}$ with the $v^{1 / 2}$ indicates a diffusioncontrolled redox process. ${ }^{25}$

The mechanism of interaction between drug molecules and DNA could be explored in three different ways. The first one is the evaluation of the changes in the electrochemical responses of DNA before and after the interaction with drugs. In addition, the interaction could be assessed by obtaining a dramatic decrease/increase at the drug's oxidation/reduction peak currents, which selectively binds to DNA. In general, the appearance or disappearance of redox signals in typical voltammograms of the drug of interest after incubating with DNA in an electrochemical cell is preferred. Finally, potential

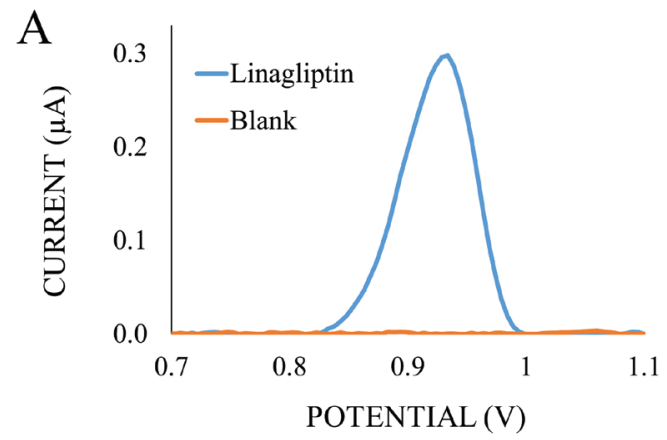

B

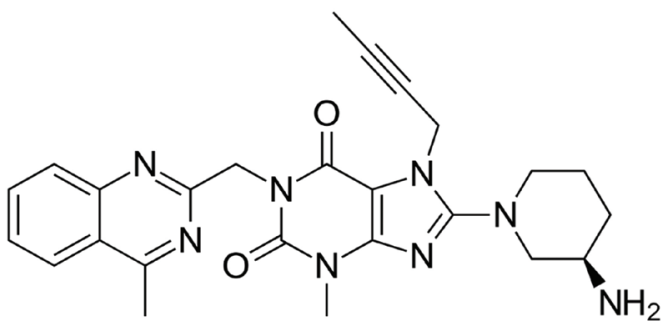

Figure 3. (A) Differential pulse voltammograms for oxidation currents of Lin obtained at nearly $+0.9 \mathrm{~V}$ in $\mathrm{ACB}$. (B) Chemical structure of Lin molecule ACB: 0.5-M acetate 
shifts to the more positive or negative side by the intercalation of nucleic acid-binding molecules into DNA could help understand the underlying mechanism of the interaction.

Our study aimed to investigate the interaction between DNA and Lin and to understand the interaction mechanism. Hence, interaction studies were performed. To optimize DNA-Lin interaction, different interaction times from 30 to 90 min were performed. Figure 5A shows the results. In the study, $400 \mu \mathrm{g} /$ $\mathrm{mL}$ of DNA and $1200 \mu \mathrm{g} / \mathrm{mL}$ of Lin were mixed in a ratio of 1:1 in ACB. Thus, $200 \mu \mathrm{g} / \mathrm{mL}$ of DNA and $600 \mu \mathrm{g} / \mathrm{mL}$ of Lin solutions were obtained. Subsequently, $100 \mu \mathrm{L}$ of the solution was transferred into the vials, and these vials were kept at interaction times ranging from 30 to $90 \mathrm{~min}$. The adenine oxidation signal was measured as 0.51 (for $30 \mathrm{~min}$ ), 0.72 (for 60 $\mathrm{min}$ ), and $0.61 \mu \mathrm{A}$ (for $90 \mathrm{~min}$ ) before DNA-Lin interaction. After the interaction between DNA and Lin, the adenine oxidation signals were 0.25 (for $30 \mathrm{~min}$ ), 0.32 (for $60 \mathrm{~min}$ ), and $0.33 \mu \mathrm{A}$ (for $90 \mathrm{~min}$ ). The highest difference between before and after the signal was observed with $60 \mathrm{~min}$. Therefore, the optimum interaction time was selected as $60 \mathrm{~min}$.

After finding the optimum conditions, the interaction between DNA and Lin was performed to investigate the behavior of Lin on DNA to understand how Lin could interact with DNA (Figure 5B). The Lin-DNA interaction was investigated in comparison to the alterations in the adenine oxidation currents in the absence and presence of Lin. In our study, guanine currents were not analyzed because their signals were close to Lin oxidation signals and could interfere.

A

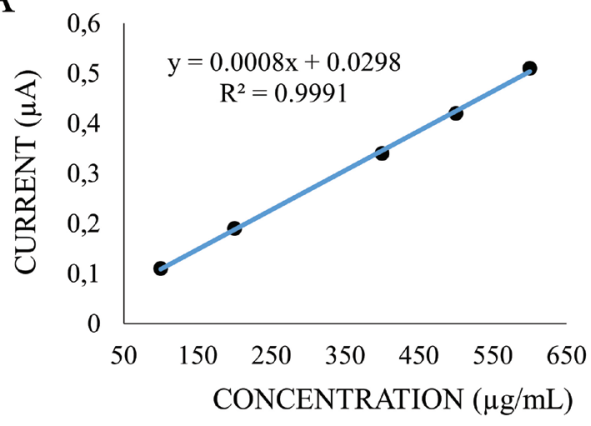

C

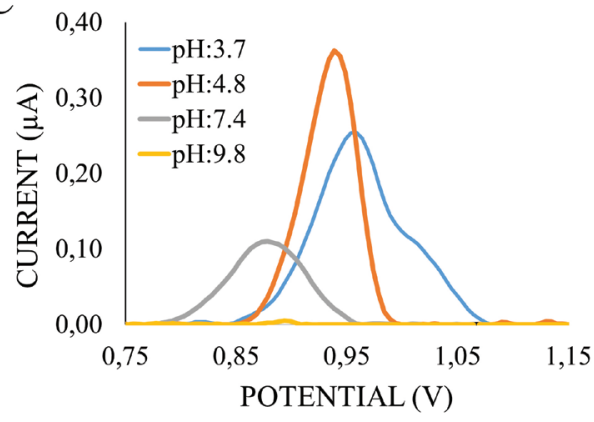

After the interaction with Lin, adenine oxidation signals were decreased. The adenine peak potential did not shift after the interaction. We assumed that the interaction of DNA with Lin leading to conformational changes in the DNA structure followed by the interaction of Lin to the adenine bases, which attenuates the electrochemical signal of adenine. This phenomenon could be explained by the shielding of the oxidizing groups of adenine or fewer base molecules being available for oxidation. ${ }^{28}$

According to the results based on adenine signals obtained from Figure 5B, the toxicity effect (S \%) of Lin on DNA was calculated using equation $5:^{29}$

$\mathrm{S} \%=\left(\mathrm{S}_{\mathrm{a}} / \mathrm{S}_{\mathrm{b}}\right) \times 100$

(equation 5)

S \%: Percentage of the adenine peak current change,

$S_{a}$ : Height of the adenine peak current after the interaction with Lin,

$\mathrm{S}_{\mathrm{b}}$ : Height of the adenine peak current before the interaction with Lin.

Generally, if the S\% value is more than 85 , it is assumed to be non-toxic. If this value is between 50 and 85, it could be moderately toxic, and if less than 50 , it is considered toxic. With this equation, the S\% value was calculated to be $44 \%$, demonstrating the toxicity of Lin to DNA.

Based on our voltammetric measurements and toxicity calculation, Lin could have toxic effects on DNA.
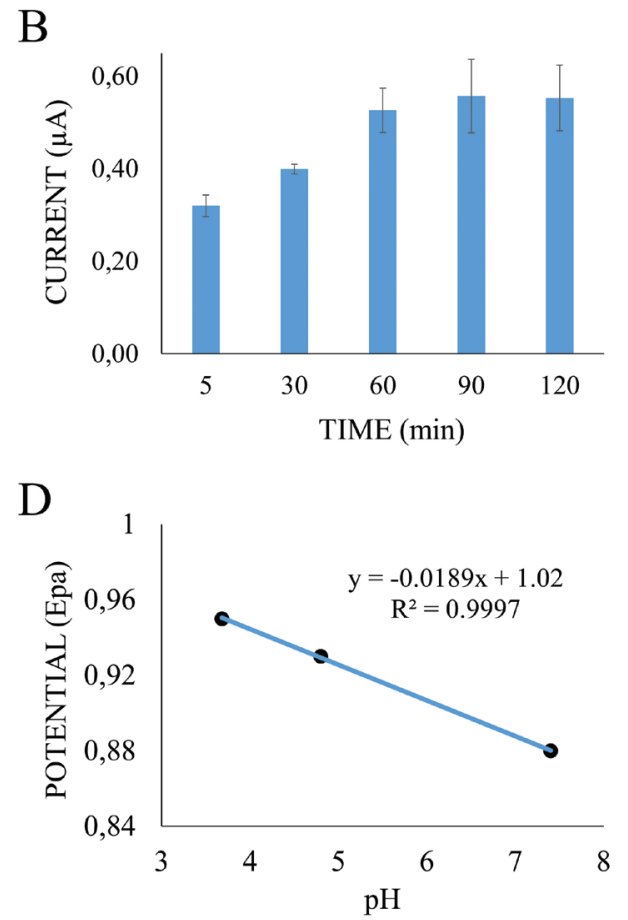

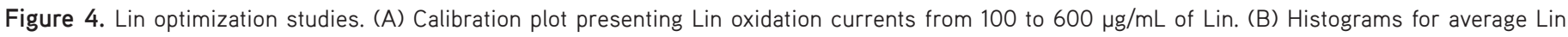

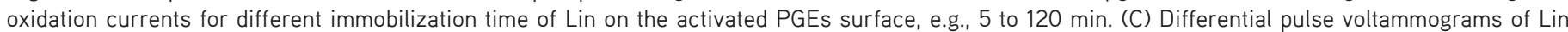
oxidation currents from different supporting electrolytes with $\mathrm{pH}$ ranging from 3.7 to 9.8. (D) $\mathrm{Plots}$ of $\mathrm{Ep}$

Lin: Linagliptin, PGEs: Pencil graphite electrodes, Ep $\mathrm{a}$ : Anodic peak potential 
A

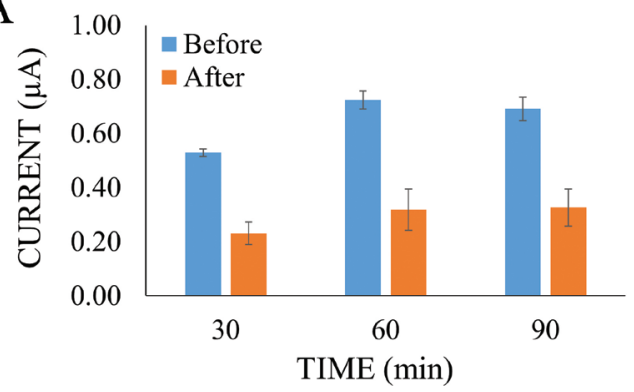

$\mathrm{B}$

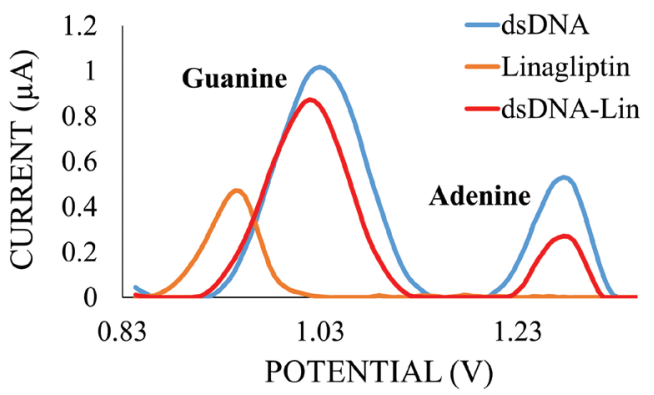

Figure 5. Interaction of DNA and Lin. (A) Histograms for average adenine oxidation signals for different interaction times between Lin and DNA e.g., 30 to 90 min. (B) Differential pulse voltammograms of guanine and adenine oxidation currents after interaction with Lin

Lin: Linagliptin, dsDNA: Double-stranded DNA

\section{CONCLUSION}

This is the first study demonstrating the electrochemical detection of the interaction between DNA and Lin using electrochemical techniques. The electrochemical properties of Lin were investigated, and the effects of DNA-Lin interaction have been explored in comparison with the alterations in the adenine oxidation peak. The interaction that occurred in the solution phase was characterized by the change in the adenine oxidation peak current before and after the incubation. According to our study, the diffusion-controlled irreversible redox process involving independent oxidation was revealed for Lin. After the interaction with Lin, the adenine oxidation signals of DNA decreased as proof of interaction. The adenine peak potential did not shift after the interaction with Lin. Our results also showed that Lin is toxic to dsDNA.

Conflict of interest: No conflict of interest was declared by the authors. The authors are solely responsible for the content and writing of this paper.

\section{REFERENCES}

1. Guarra F, Marzo T, Ferraroni M, Papi F, Bazzicalupi C, Gratteri P, Pescitell, G, Messori L, Biver T, Gabbiani C. Interaction of a gold(I) dicarbene anticancer drug with human telomeric DNA G-quadruplex: solution and computationally aided X-ray diffraction analysis. Dalton Trans. 2018;47:16132-16138.

2. Morawska K, Poplawski T, Ciesielski W, Smarzewska S. Electrochemical and spectroscopic studies of the interaction of antiviral drug Tenofovir with single and double stranded DNA. Bioelectrochemistry. 2018;123:227232.

3. Sirajuddin M, Ali S, Badshah A. Drug-DNA interactions and their study by UV-Visible, fluorescence spectroscopies and cyclic voltametry. J Photochem Photobiol B. 2013;124:1-19.

4. Topkaya SN, Cetin AE. Determination of Electrochemical interaction between 2-(1H-benzimidazol-2-yl) phenol and DNA sequences. Electroanalysis. 2019;31:1554-1561.

5. Shahabadi N, Fili SM, Kheirdoosh F. Study on the interaction of the drug mesalamine with calf thymus DNA using molecular docking and spectroscopic techniques. J Photochem Photobiol B. 2013;128:20-26.
6. Lima D, Hacke ACM, Inaba J, Pessôa CA, Kerman K. Electrochemical detection of specific interactions between apolipoprotein $E$ isoforms and DNA sequences related to Alzheimer's disease. Bioelectrochemistry. 2020;133:107447.

7. Ensafi AA, Kazemnadi N, Amini M, Rezaei B. Impedimetric DNA-biosensor for the study of dopamine induces DNA damage and investigation of inhibitory and repair effects of some antioxidants. Bioelectrochemistry. 2015;104:71-78.

8. Bi S, Yan L, Wang Y, Pang B, Wang T. Spectroscopic study on the interaction of eugenol with salmon sperm DNA in vitro. $J$ Lumin. 2012;132:2355-2360.

9. Kirsch P, Jakob V, Elgaher WAM, Walt C, Oberhausen K, Schulz TF, Empring M. Discovery of Novel Latency-Associated Nuclear Antigen Inhibitors as Antiviral Agents Against Kaposi's Sarcoma-Associated Herpesvirus. ACS Chem Biol. 2020;15:388-395.

10. Khan RA, Arjmand F, Tabassum S, Monari M, Marchetti F, Pettinari C. Organometallic ruthenium(II) scorpionate as topo Il $\alpha$ inhibitor; in vitro binding studies with DNA, HPLC analysis and its anticancer activity. J Organomet Chem. 2014;771:47-58.

11. Asghar F, Fatima S, Rana S, Badshah A, Butler IS, Tahir MN. Synthesis, spectroscopic investigation, and DFT study of $\mathrm{N}, \mathrm{N}^{\prime}$-disubstituted ferrocene-based thiourea complexes as potent anticancer agents. Dalton Trans. 2018;47:1868-1878.

12. Loo FC, Ng SP, Wu CML, Kong SK. An aptasensor using DNA aptamer and white light common-path SPR spectral interferometry to detect cytochrome-c for anti-cancer drug screening. Sens Actuators B Chem. 2014; 198:416-423.

13. Adeniji SE, Adamu Shallangwa G, Ebuka Arthur D, Abdullahi M, Mahmoud AY, Haruna A. Quantum modelling and molecular docking evaluation of some selected quinoline derivatives as anti-tubercular agents. Heliyon. 2020;6:e03639.

14. McGill JB. Linagliptin for type 2 diabetes mellitus: a review of the pivotal clinical trials. Ther Adv Endocrinol Metab. 2012;3:113-124.

15. El-Shal MA, Azab SM, Hendawy HAM. A facile nano-iron oxide sensor for the electrochemical detection of the anti-diabetic drug linagliptin in the presence of glucose and metformin. Bulletin of the National Research Centre. 2019;43:95.

16. Rizk M, Attia AK, Mohamed HY, Elshahed MS. Validated voltammetric method for the simultaneous determination of anti-diabetic drugs, 
linagliptin and empagliflozin in bulk, pharmaceutical dosage forms and biological fluids. Electroanalysis. 2020;32:1737-1753.

17. Aref HA, Hammad SF, Elgawish MS, Darwish KM. Novel spectrofluorimetric quantification of linagliptin in biological fluids exploiting its interaction with 4-chloro-7-nitrobenzofurazan. J Lumin. 2020;35:626-635.

18. Hanafy A, Mahgoub H. A Validated HPLC method for the determination of linagliptin in rat plasma. Application to a pharmacokinetic study. J Chromatogr Sci. 2016;54:1573-1577.

19. Mourad SS, El-Kimary El, Hamdy DA, Barary MA. Stability-indicating HPLC-DAD method for the determination of linagliptin in tablet dosage form: application to degradation kinetics. J Chromatogr Sci. 2016;54:1560-1566.

20. Ahmadi M, Ahour F. An electrochemical biosensor based on a graphene oxide modified pencil graphite electrode for direct detection and discrimination of double-stranded DNA sequences. Analytical Methods. 2020 .

21. Zhang $Y$, Zhang WB, Liu C, Zhang P, Balaeff A, Beratan DN. DNA charge transport: Moving beyond 1D. Surface Science. 2016;652:33-38.

22. Kogikoski S, Paschoalino WJ, Cantelli L, Silva W, Kubota LT. Electrochemical sensing based on DNA nanotechnology. Trends Anal Chem. 2019;118:597-605.

23. J. N. miller JCm. Statistics and Chemometrics for Analytical Chemistry: 5th pearson education, Essex, London 2005. 121 p.
24. Aftab S, Kurbanoglu S, Ozcelikay G, Bakirhan NK, Shah A, Ozkan SA. Carbon quantum dots co-catalyzed with multiwalled carbon nanotubes and silver nanoparticles modified nanosensor for the electrochemical assay of anti-HIV drug Rilpivirine. Sensors and Actuators B: Chemical. 2019;285:571-583.

25. Fekry AM, Shehata M, Azab SM, Walcarius A. Voltammetric detection of caffeine in pharmacological and beverages samples based on simple nano- Co (II, III) oxide modified carbon paste electrode in aqueous and micellar media. Sensors and Actuators B: Chemical. 2020;302:127172.

26. Mahmoud BG, Khairy M, Rashwan FA, Banks CE. Simultaneous voltammetric determination of acetaminophen and isoniazid (hepatotoxicity-related drugs) utilizing bismuth oxide nanorod modified screen-printed electrochemical sensing platforms. Analytical Chemistry. 2017;89:2170-2178.

27. Mohamed MA, El-Gendy DM, Ahmed N, Banks CE, Allam NK. 3D spongy graphene-modified screen-printed sensors for the voltammetric determination of the narcotic drug codeine. Biosensors and Bioelectronics. 2018;101:90-95.

28. Rauf S, Nawaz H, Akhtar K, Ghauri MA, Khalid AM. Studies on sildenafil citrate (Viagra) interaction with DNA using electrochemical DNA biosensor. Biosensors and Bioelectronics. 2007;22:2471-2477.

29. Bagni G, Osella D, Sturchio E, Mascini M. Deoxyribonucleic acid (DNA) biosensors for environmental risk assessment and drug studies. Analytica Chimica Acta. 2006;573-574:81-89. 